\title{
NICHOLAS OF CUSA AND MARTIN LUTHER ON ISLAM
}

\author{
Walter Andreas Euler \\ Faculty of Theology, University of Trier
}

\begin{abstract}
The article compares for the first time Luther's reflections on Islam with Cusanus's. Both thinkers didn't engage in Islam on their own initiative, but because they were prompted by political developments. Luther's writings on Islam are mostly authored in German. He addresses the public in the empire and tries to encourage Christians challenged in their Christians faith, especially those who are in Turkish captivity. Nicholas of Cusa addresses also Islamic receivers in his Cribratio Alkorani. Luther stresses the contrast between the gospel of Jesus Christ and the message of Muhammad, whereas Cusanus tries to build theological bridges between Christianity and Islam.
\end{abstract}

\section{Keywords}

Koran; Muhammad; defense; apocalyptic threat; exclusivism; integration

Europe's intellectual elites, in the transition from the late Middle Ages to the early modern period, generally did not engage in Islam on their own initiative, but because they were prompted by political developments. In the 15th and 16th century, the Ottoman advance shocked Westerners, so that Islam is increasingly called the Turkish religion during this period. Although Nicholas of Cusa had already dealt with Islam at the time of the Council of Basel, it was the fall of Constantinople on May 29, 1453, which led him to write De pace fidei. This turning point in world history prompted Juan de Segovia to write a letter to Nicholas on the subject of Islam, which he answered on December 29,1454 . In his 294 sermons, ${ }^{1}$ he comes only once more to speak at

${ }^{1} 293$ of Cusanus's sermons have been edited by R. Haubst, et al. in: Nicolaus de Cusa, Opera omnia iussu et auctoritate academiae litterarum Heidelbergensis, vols. XVI, XVII, XVIII, 
length on Islam, in the first part of the Sermo CCXL, which was given in a procession in thanksgiving for the victory over the Turks at Belgrade on August 24, 1456. Also Cribratio Alkorani was known to be motivated by an external impulse, namely the intention of Pope Pius II, to convince Sultan Mehmed II by a teaching letter on the truth of the Christian faith. ${ }^{2}$

While in Central Europe the conflict over the right understanding of the Christian faith gradually led to the dissolution of intra-Christian unity, Sultan Suleiman I, the Magnificent, took up the military successes of Mehmed II. In 1521 Belgrade was conquered, in 1526 the Hungarian army was defeated, and in autumn of 1529 the Turks besieged Vienna. In view of the increasing threat for the empire by the Turks, the reformer Martin Luther was forced, as he himself states, to give a detailed statement on Islam. The title of this first book on the Turks («Türkenbuch») of Luther in April 1529 reads: Vom Kriege wider die Türken (On War against the Turk). In 1530 appeared Eine Heerpredigt wider den Türken (An Army Sermon against the Turk). These two writings, as well as most of Luther's later statements on Islam, were written in German. Luther addressed himself to the public in the empire, where he had been declared by his opponents, especially from the Catholic camp, to be responsible for the advance of the Turks. ${ }^{3}$ Luther declares at the beginning of On War against the Turk:

Serene, highborn prince, gracious lord, for the past five years certain persons have been begging me to write about war against the Turks, and to arouse and encourage our people. Now that the Turk is actually approaching, even my friends are urging me to do this, especially since there are some stupid preachers among us Germans (as I am sorry to hear) who are making the people believe that we ought not and must not fight against the Turks. Some are even so foolish as to say that it is not proper for Christians to bear the temporal sword or to be rulers. Furthermore, some actually want the Turk to come and rule because they think our German people are wild and uncivilized - indeed, that they are half-devil and half-man. The blame for this wicked error among the people is laid on Luther and must be called 'the

and XIX, Hamburg, Felix Meiner, 1991-2008. Another sermon was recently discovered by Marco Brösch.

${ }^{2}$ Euler, W.A., and Kerger, T. (eds.), Cusanus und der Islam, Trier, Paulinus, 2010; Euler, W.A., "A Critical Survey of Cusanus's Writings on Islam», in I.C., Levy, R. GeorgeTvrtković and D.F. Duclow (eds.), Nicholas of Cusa and Islam. Polemic and Dialogue in the Late Middle Ages, Leiden - Boston, Brill, 2014, pp. 20-29.

${ }^{3}$ Francisco, A.S., Martin Luther and Islam. A Study in Sixteenth-Centure Polemics and Apologetics, Leiden - Boston, Brill, 2007. 
fruit of my Gospel,' just as I am blamed for the rebellion, and for every bad thing that happens anywhere in the world. ${ }^{4}$

In the various indices of the large critical edition of Luther's works, letters and Table Talk («Tischreden»), we can see that topics like «Turkey, Turk, Turkish, etc.» played a great role for him and his environment. ${ }^{5}$

The idea of comparing for the first time Luther's reflections on Islam with Cusanus's goes back to a lecture entitled: «Die Einstellung der Reformatoren des 16. Jahrhunderts zu Nikolaus von Kues» (The Attitude of the Reformers of the 16th Century to Nicholas of Cusa), which I delivered last October on the occasion of the 500th anniversary of the Reformation, in the birthplace of Cusanus in Bernkastel-Kues. In preparing this lecture I have been reminded that Luther once referred to Cusanus. This happened in the foreword to the Libellus de ritu et moribus Turcorum (Tract on the Religion and Customs of the Turks), which Luther published in 1530. This fifteenth-century work is a report by a Dominican friar from Transylvania, Georgius de Hungaria, who spent 20 years in Turkish captivity. Luther writes in his Latin preface that he desperately wants to know the religion of the Turks, but he has found until that moment only two writings on the subject: a certain Confutatio Alkorani and the Cribratio Alkorani of Nicholas of Cusa (Cribratio Alkorani Nicholai de Cusa). He did not yet know the Koran at that time.

So Luther knew the most important work of Cusanus on Islam and the name of its author. But he had great reservations about the two writings he mentioned. They seemed to him to be less reliable than the book of Georgius de Hungaria, as we see in the following quote:

I gladly accepted this little book on the religion and customs of the Turks when it was offered to me. Now I have decided to publish it, not without good reason as it seems to me. Although I have eagerly desired for some time to learn about the religion and customs of the Muhammadans, nothing has been available to me except a certain Refutation of the Alcoran and the Critique of the Alcoran by Nicholas of Cusa; I have tried in vain to read the Qur'ān itself. The authors of the Refutation and the Critique seem to have intended through pious examination to frighten sincere Christians away from Muhammadanism and hold them secure in their faith in Christ. Still, while they eagerly take pains to excerpt from the Qur'ān all the most base and absurd things

${ }^{4}$ Luther, M., On War Against the Turk, ed. R. C. Schultz, in Luther's Works, vol. 46, Philadelphia, Fortress Press, 1967, pp. 161-205, at p. 161; Luther, M., Vom Kriege wider die Türken, eds. F. Cohrs and A. Goetze, in Luther, M., Werke. Kritische Gesamtausgabe, vol. 30/2, Weimar, Hermann Böhlaus Nachfolger, 1909, pp. 107-148, at p. 106,6-20.

${ }^{5}$ Brecht, M., «Luther und die Türken», in: Guthmüller B., and Kühlmann W., (eds.), Europa und die Türken in der Renaissance, Tübingen, Max Niemeyer, 2000, pp. 9-27, at p. 9. 
that arouse hatred and can move people to ill-will, at the same time they either pass over without rebuttal or cover the good things it contains. The result is that they have achieved too little credibility or authority, as it were cheapening their work either because of hatred of the Turks or because of their own lack of powers of refutation. ${ }^{6}$

This characterization corresponds more to the first work called by him Confutatio Alkorani, also known under the title Contra legem Sarracenorum, a work of the Florentine Dominican friar and Orient Missionary Ricoldo da Montecroce (1243-1320) than to the Cribratio Alkorani of Nicholas of Cusa. Incidentally, Luther revised his judgment thoroughly in relation to Ricoldo's writing. In 1542 he published his own German translation of the book - with extensive cuts on the one hand, and his own additions on the other - under the title Verlegung des Alcoran (Refutation of the Koran). Luther read the Koran in the Latin translation of Robert of Ketton on Shrove Tuesday in 1542. Thus he came to the conviction that those things that Ricoldo, who was called by him Brother Richard, had to criticize about Islam, were not too negative, but fully corresponded to the statements of the Koran. He writes:

This book by Brother Richard of the Order of Preachers, entitled Refutation of the Koran, I had read several times before, but I could not believe that there were rational human beings on this earth who could be persuaded by the Devil to believe such shameful things. ... But now, this past Shrove Tuesday, I have seen the Koran in Latin, though so poorly translated that I still hope to see a clearer one. But from it I observed, at least, that this brother Richard did not make up the material in his book; rather, it corresponds to [the Koran] exactly. ${ }^{7}$

As for the appreciation of the book of Ricoldo da Montecroce, Cusanus agrees with the judgment of Luther in 1542. The cardinal mentions his sources in the first prologue of the Cribratio and emphasizes in particular Ricoldo's book: «Thereafter, in Rome, I saw the book of Brother Ricoldo, of the Order of

${ }^{6}$ Henrich, S. and Boyce, J.L., «Martin Luther - Translations of Two Prefaces on Islam: Preface to the Libellus de ritu et moribus Turcorum (1530) and Preface to Bibliander's Edition of the Qur'än (1543)», Word \& World, 16 (1996), pp. 250-266, at p. 258; Luther, M., Vorwort zu dem Libellus de ritu et moribus Turcorum, ed. O. Clemen, in Luther, M. Werke. Kritische Gesamtausgabe, vol. 30/2, Weimar, Hermann Böhlaus Nachfolger, 1909, pp. 205-208, at p. 205,2-15.

${ }^{7}$ Luther, M., Preface and Afterword to Brother Richard O.P. [Riccoldo da Monte di Croce], Refutation of the Koran, ed. A. S. Francisco, in Luther's Works, vol. 60, ed. C. B. Brown, Saint Louis, Concordia Publishing House, 2011, pp. 253-266, at pp. 253-254. Luther, M., Verlegung des Alcoran Bruder Richardi, Prediger Ordens, eds. H. Barge and O. Brenner, in Luther, M., Werke. Kritische Gesamtausgabe, vol. 53, Weimar, Hermann Böhlaus Nachfolger, 1920, pp. 272-396, at p. 272,3-6.16-19. 
the Preachers, who studied Arabic in Bagdad; this [book] was more gratifying than the others.» ${ }^{8}$ In the course of the writing Ricoldo is repeatedly mentioned with praise. Cusanus calls him "a certain wise man»" and «a certain devout man knowing Arabic» ${ }^{10}$. The «Index auctorum» of the critical edition of the Cribratio shows how often Nicholas refers to Ricoldo's book Contra legem Sarracenorum..$^{11}$

The question why Luther worked much less with the book of Nicholas of Cusa than with that of Ricoldo da Montecroce cannot be answered, because Luther does not comment on this subject. Cusanus' approach of sifting the Koran critically or rather to read it dialectically - at once with a view to the positive, but also with a sharp emphasis on the negative aspects - makes it difficult to use his book as a basis for a clear judgment. Even Pope Pius II doesn't refer to the Cribratio in his letter to Mehmed II, although this work was written for him. In the critical edition of the Verlegung, however, it is pointed out, among other things, that Luther's marginal note «Hic Sergius Monachus $\rangle^{12}$ goes back to the Cribratio Alkorani. ${ }^{13}$ This shows that the reformer can not have read Cusanus' writing only superficially.

Let us now take a look at the theological conceptions of Cusanus and Luther towards Islam:

Why does God allow that there could emerge a new religion and political as well as military power in Arabia 600 years after the death of Christ on the cross, a new religion which causes so many difficulties for the true Christian religion? This question tormented the theologians of the Middle Ages more than those of today. The most convincing answer according to them, especially on the basis of the Old Testament and the behavior of the ancient people of the God of the Israelites, is the one we find in different variations also in Nicholas of Cusa and Martin Luther. Islam is a rod of God to punish the transgressions of the Christians, and at the same time a tool of the devil.

\footnotetext{
${ }^{8}$ Hopkins, J., Nicholas of Cusa's De pace fidei and Cribratio Alkorani: Translation and Analysis, Minneapolis, The Arthur J. Banning Press, 1994, p. 76; Nicolaus de Cusa, Cribratio Alkorani, ed. L. Hagemann, in: Nicolaus de Cusa, Opera omnia iussu et auctoritate academiae litterarum Heidelbergensis, vol. VIII, Hamburg, Felix Meiner, 1986, \# 4,3-5 (p. 6).

${ }^{9}$ Hopkins, Nicholas of Cusa's De pace fidei and Cribratio Alkorani, op. cit., p. 89; Nicolaus de Cusa, Cribratio Alkorani, op. cit., \# 29,2 (p. 29).

${ }^{10}$ Hopkins, Nicholas of Cusa's De pace fidei and Cribratio Alkorani, op. cit., p. 93; Nicolaus de Cusa, Cribratio Alkorani, op. cit., \# 37,6 (p. 35).

${ }^{11}$ Nicolaus de Cusa, Cribratio Alkorani, op. cit., pp. 311-313.

${ }^{12}$ Luther, M., Verlegung des Alcoran Bruder Richardi, Prediger Ordens, op. cit., p. 288,25.

${ }^{13}$ Ibid., pp. 288-290 (note 8); Nicolaus de Cusa, Cribratio Alkorani, op.cit., \# 11,2-4 (p. 13).
} 
In his letter to Juan de Segovia, Cusanus notes that scourges often occur when tepiditas, lukewarmness creeps into the church. He cites as an example the plundering of Rome by the Saracens in 846. God hates lukewarmness because he is a jealous God. If the lukewarmness were eliminated, the plagues would disappear. The Cardinal concludes: «I firmly believe that the persecution is not permitted for death, but for life, not for annihilation, but for the glorification of the faith. Because the church has this peculiarity that it shines out under the persecution.» ${ }^{14}$

In sermon CCXL, Cusanus says the "fraudulent schismatics», which means the Orthodox Christians, who did not support union with the Latin Church, which had been declared in 1439 at the Council of Florence, would be restored to the right path by the fall of Constantinople, and the good people who were driven out would drive the Christians out of their lukewarmness. ${ }^{15}$ The Turkish scourge would wake the drowsy Christians. Cusanus concludes the part of the sermon that deals with the Belgrade victory by saying: «God will prove to be the loyal guardian of us Christians if we, filled with faith, seek refuge in him, knowing that we will undoubtedly be saved ${ }^{16}$ if we trust in his protection, willingly and with all our heart. ${ }^{17}$

In his Cribratio Nicholas refers to the devil in one place explicitly as the author of the Koran:

${ }^{14}$ Nicolaus de Cusa, Epistola ad Ioannem de Segobia, eds. R. Klibansky and H. Bascour, in Nicolaus de Cusa, Opera omnia iussu et auctoritate academiae litterarum Heidelbergensis, vol. VII, Hamburg, Felix Meiner, 1959, pp. 93-102, at p. 100, 16-25: «Nam pluries tepiditate Ecclesiam subintrante excitata sunt flagella. Venerunt Romam aliquando Sarraceni et Ecclesiam sancti Petri depraedarunt; excitata dormiens Ecclesia ad Dominum habuit refugium. Odit Deus tepiditatem, quia Deus zelotes. Unde, si occasiones tollerentur quare contra nos sed pro nostra salute et decore Ecclesiae Christus ista permittit, esset infallibile remedium. Ego firmissime credo non ad mortem sed vitam, non ad suppressionem sed exaltationem fidei persecutionem permitti. Ecclesia hoc proprium habet quod sub persecutione splendescit.»

${ }^{15}$ Nicolaus de Cusa, Sermo CCXL, eds. W. A. Euler and H. Schwaetzer, in Nicolaus de Cusa, Opera omnia iussu et auctoritate academiae litterarum Heidelbergensis, vol. XIX, Hamburg, Felix Meiner, 2002, pp. 228-234, \# 4,1-4 (p. 229).

${ }^{16}$ Here, Nicholas alludes not only to the eternal salvation, but also to the rescue from the threat of the Turks.

${ }^{17}$ Nicolaus de Cusa, Sermo CCXL, \# 5 (pp. 230-231): «Haec est dies boni nuntii, in quo recepimus plures litteras huius miraculosae victoriae. Quapropter convenimus, ut laudemus Deum, qui mirabili ordine memoriam crucis renovavit, agente hoc per flagellum, quo somnolenti excitaremur ac quod invocemus eum, qui ostendit se pium protectorem, quando tota fide ad ipsum recurrimus, scientes quia indubie salvi erimus, si ex toto corde nos suae tuitione commendaverimus.» 
The author of the book [= the Koran] will be someone other than the true God; but he cannot be anyone except the god of this world. For this god is he who blinds the minds of unbelievers, so that the light of the Gospel of the glory of Christ, who is the image of the invisible God, does not shine in them; ... This god, or prince, of this world, who from the beginning is a liar, encountered the man Muhammad through the person of one of his own angels who assumed the appearance of light and perhaps the name 'Gabriel'. This god found that the idolater Muhammad, who was worshipping Venus and lusting after all the things of this world, was most suitable for his purpose. And through Muhammad, chiefly, and his successors he put together the deceitful Koran. ${ }^{18}$

Luther is certain that Islam or the «Turk» is the scourge of God and at the same time a tool of the devil. In his theocentric view of the world, in pestilence, war, riots, earthquakes, murders, Turks, and Tartars, the will of God is expressed, thus punishing his unruly people in the sense of Isaiah 10:5. The thesis that God uses the infidels, specifically the Turks, to chastise his people, already offered Luther the opportunity in 1518, even before the ultimate break with Rome, for a church-critical update: Many in the Church, especially the powerful, and mainly the Pope, would propagate crusades against the Turks. This means that they would rather fight against the divine rod, with which God punishes the sins, than against the misdeeds themselves. ${ }^{19}$ To avoid this mistake, Luther emphasizes in his book On War Against the Turk:

Since the Turk is the rod of the wrath of the Lord our God and the servant of the raging devil, the first thing to be done is to smite the devil, his Lord, and take the rod out of God's hand, so that the Turk may be found only, in his own strength, all by himself, without the devil's help and without God's hand. This should be done by Sir Christian, that is, by the pious, holy, precious body of Christians. They are the people who have the arms for this war and they know how to use them. ${ }^{20}$

The weapons of the true Christians, with which they appease God and conquer the devil, are unconditional faith in the salvific act of Christ in conjunction with change, repentance and prayer. In a 1542 Table Talk, Luther said that the prayer of the poor children, especially their Lord's Prayer helps better in the face of the Turkish threat than protective walls, rifles and the

${ }^{18}$ Hopkins, Nicholas of Cusa's De pace fidei and Cribratio Alkorani, op. cit., 86; Nicolaus de Cusa, Cribratio Alkorani, op. cit., \# 23,1-2.5-10 (pp. 23-24).

${ }^{19}$ Kaufmann, T., «Türckenbüchlein». Zur christlichen Wahrnehmung «türkischer Religion» in Spätmittelalter und Reformation, Göttingen, Vandenhoeck \& Ruprecht, 2008, p. 73.

${ }^{20}$ Luther, M., On War Against the Turk, op. cit., p. 170; Luther, M., Vom Kriege wider die Türken, op. cit., p. 116,26-32. 
actions of all princes. ${ }^{21}$ The military struggle against the Turks is legitimate for Luther, and indeed a civic duty, if the Turks invade as foreign aggressors. This fight must be ordered and directed by the rightful secular authority, Emperor Karolus (= Charles V), according to the two-kingdoms-doctrine.

Luther rejected without compromise the medieval idea of the crusade, that is to say, a war that serves religious purposes and promises salvation for serving the Christian cause. He was convinced that there was no justification for the war against the Turks if they did not pose a threat. One must bear their erroneous beliefs as well as those of the bad Christians, among whom Luther, of course, counted his Roman opponents, but also many of his followers and sometimes even himself. "Let the Turk believe and live as he will, just as one lets the papacy and other false Christians live. The emperor's sword has nothing to do with the faith.» ${ }^{22}$

In the Army Sermon Against the Turk, Luther urges Christians, who have fallen into Turkish captivity, to obey their Islamic masters unless they force them to renounce the Christian faith and fight against Christians themselves. The most interesting aspect of this work is Luther's advice that Christians who find themselves in Ottoman lands should not attempt to flee, but rather they should accept their fate and, while constantly reminding themselves of their righteousness before God in Christ, should strive to do their best to love and serve the Turks. ${ }^{23}$

Sermo CCXL makes clear that Nicholas of Cusa also supported the idea of military resistance to the expansion of the Turks. In his letter to Juan de Segovia, he writes that defense alone is without danger for the Christians. ${ }^{24}$ As cardinal of the Curia, Cusanus served from 1458 onwards under Pope Pius II, who saw it as his most important task to initiate a pan-European crusade against the Turks. Whether Nicholas of Cusa supported this idea of the head of

${ }^{21}$ Luther, M., Werke. Kritische Gesamtausgabe. Tischreden, vol. 5, Weimar, Hermann Böhlaus Nachfolger, 1920; \# 5398 (p. 127).

${ }^{22}$ Luther, M., On War Against the Turk, op. cit., p. 186; Luther, M., Vom Kriege wider die Türken, op. cit., p. 131,6-9.

${ }^{23}$ Francisco, A.S., «Luther, Lutheranism, and the Challenge of Islam», Concordia Theological Quaterly, 71 (2007), pp. 283-300, at p. 290; Luther, M., Heerpredigt wider den Türken, eds. F. Cohrs and A. Goetze, in Luther, M., Werke. Kritische Gesamtausgabe, vol. 30/2, Weimar, Hermann Böhlaus Nachfolger, 1909, pp. 160-197, at pp. 185-195.

${ }^{24}$ Nicolaus de Cusa, Epistola ad Ioannem de Segobia, op. cit., p. 97,5-11: «Assentio igitur rationibus vestris fundatissimis tam in iure divino quam humano; quia si iuxta doctrinam Christi processerimus, non errabimus, sed spiritus eius loquetur in nobis, cui non poterunt omnes adversarii Christi resistere; sed si invasionis gladio aggressionem eligerimus, formidare habemus ne gladio pugnantes gladio pereamus. Unde sola defensio sine periculo est Christiano.» 
the church on the basis of his own conviction and not only by virtue of his office, cannot be determined.

With regard to the Koran and the person of Muhammad, Cusanus in his Cribratio is much more detailed and differentiated than Luther in his writings on the Turks. Although Nicholas of Cusa was convinced that the devil was the author of the Koran, his judgment on the «book of Arab law»" ${ }^{25}$ or the «Book of Muhammad $»^{26}$, as he names the Koran, is by no means only negative. Pia interpretatione, due to pious, Christian interpretation, the Koran could be considered as a secret Gospel, ${ }^{27}$ yet it is the product of a debauchee who only ever cared for glory, might and wealth. In succession of the older Christian apologetic, Cusanus claims that Mohammed died as a heretic Christian. ${ }^{28} \mathrm{His}$ knowledge of the truth was contaminated by ignorantia, ignorance, and perversitas intentionis, perverse intentions.$^{29}$ Moreover, tres astutissimi Judaei, three extremely sly Jews had added anti-Christian amendments to the Koran, ${ }^{30}$ resulting in an even further alienation from Christianity.

Thus, in Cribratio Alkorani Cusanus considers the holy book of the Muslims to be a book containing contradictory tendencies regarding its content, as well as a confusissimus liber concerning its form, a highly abstruse creation because every single chapter has to be analysed separately, as the different paragraphs were not coherently connected with each other. Nicholas of Cusa says forthrightly at the end of his second preface that he did not succeed in discerning a clear order in the Koran. That was why his interpretations of the text were rather confusing too. ${ }^{31}$

The difference between Christianity and Islam is for Cusanus that of primitive animality on the one hand and spirituality which overcomes sensuality on the other. Nicholas of Cusa clearly emphasizes this difference in the sermon CCXL, which, unlike the Cribratio, applies to a sole Christian group of addressees:

The law of Christ is the law of the Spirit, which speaks of the love of the Spirit, through which love our spirit is intimately bound to the Spirit, who is

${ }^{25}$ Nicolaus de Cusa, Cribratio Alkorani, op. cit., \# 20,3 (p. 21): «Est liber legis Arabum Alkoranus ob praeceptorum collectionem».

${ }^{26}$ Ibid., \# 10,1-2 (p. 11): «Intentio autem nostra est praesupposito evangelio Christi librum Mahometi cribrare».

${ }^{27}$ Cusanus uses the term pia interpretatio only in the second book of Cribratio Alkorani: Ibid., \# 86,4-6 (p. 72), \# 119, 1-2 (p. 94); \# 124,3-4 (p. 99); \# 154,8-9 (p. 125).

${ }^{28}$ Ibid., \# 11 (p. 13).

${ }^{29}$ Ibid., \# 9-10 (pp. 11-12).

${ }^{30}$ Ibid., \#11, 8-10 (p. 11).

${ }^{31}$ Ibid., \# 16,3-10 (p. 17). 
God, nourished and animated with indescribable and immortal joy. Since the animal-like man can understand the happy life only in an animal-like and sensuous way, the devil, who wanted to poison the gospel in a subtle way, presented the pseudo-prophet Mohammed as an expert of the Gospel and the Holy Scripture, so that he gives him an animal-like understanding, which is pleasing to the animal-like man. Therefore, he (= Mohammad) praised Christ and the Gospel, but he added to this a false understanding by promising a paradise of lust according to the flesh and bodily pleasures. ${ }^{32}$

In the Cribratio Cusanus' argument in the beginning is quite similar. ${ }^{33}$ But he offers his readers in this document with reference to "some who want to excuse the author of the Koran» a far more sophisticated interpretation of the Islamic conception of paradise. ${ }^{34}$

Martin Luther has systematized his criticism of the Koran, which often coincides with that of Cusanus, in a remarkable way in On War Against the Turk. For him, Islam is a kind of patchwork religion that feeds on Jewish, Christian and pagan traditions, ${ }^{35}$ but ultimately pursues three clearly identifiable purposes. Islam wants to destroy the Christian religion, the public order as well as marriage and family, i.e. the three cornerstones on which the society is built.

The destruction of the Christian faith is reached by the fact that the Koran praises Christ indeed, but regards him only as a prophet like Jeremiah and Jonah, whose task ended with his death. Conversely, it is clear: «Mohammed's office is still in force». ${ }^{36}$ Secondly, Islam is destroying «the whole temporal government», ("das gantz weltlich Regiment»), ${ }^{37}$ i.e. the political or public order. Luther's reasoning for his thesis is: «Mohammed ... commands that ruling is to be done by the sword, and in his Koran the sword is the commonest and noblest work. $\rangle^{38}$ With reference to Augustine and several passages in the Holy Scripture, Luther makes clear that political power is often associated with criminal violence, but unlike any other kingdom in the world, it is the Turks' practice to commit crimes as divine commandments.

${ }^{32}$ Nicolaus de Cusa, Sermo CCXL, \# 2,8-22 (pp. 228-229).

${ }^{33}$ Nicolaus de Cusa, Cribratio Alkorani, op. cit., \# 149-150,4 (p. 121).

${ }^{34}$ Ibid., \# 150,5-152,3.

${ }^{35}$ Luther, M., On War Against the Turk, op. cit., p. 177; Luther, M., Vom Kriege wider die Türken, op. cit., pp. 122,29-123,5.

${ }^{36}$ Luther, M., On War Against the Turk, op. cit., p. 177; Luther, M., Vom Kriege wider die Türken, op. cit., p. 122,14-15.

${ }^{37}$ Luther, M., On War Against the Turk, op. cit., p. 178; Luther, M., Vom Kriege wider die Türken, op. cit., p. 123,20.

${ }^{38}$ Luther, M., On War Against the Turk, op. cit., p. 178; Luther, M., Vom Kriege wider die Türken, op. cit., p. 123,21-22. 
The essential task of the state to serve the inner and outer peace is rendered impossible by the instructions of the Koran. Luther writes:

Never has any kingdom come into being and become so mighty through murder and robbery as that of the Turk; and he murders and robs every day, for robbing and murdering, devouring and destroying more and more of those that are around them, is commanded in their law as a good and divine work; and they do this and think that they are doing God a service. ${ }^{39}$

Thirdly, Islam also destroys the marital estate by allowing a man to marry several women and to get divorced from his wife at any time. Luther remarks very astutely:

Although there may be some few who do not take advantage of this law ${ }^{40}$, nevertheless, this is the law and anyone who wants to can follow it. That kind of living is not and cannot be marriage, because none of them takes or has a wife with the intention of staying with her forever, as though the two were one body, as God's Word says in Genesis 3 [2:24], »Therefore a man cleaves to his wife and they become one flesh. $\rangle^{41}$

Luther's fundamental criticism of Islam goes beyond the conception of Cusanus with reference to the second and the third point. Of course, the Cardinal also criticizes the affinity to violence in Islam («the sword is the final decisive proof of whatever is read in the Koran» he writes in the Cribratio $^{42}$ ). He condemns as well the Islamic practice of polygamy..$^{43}$ On the other side he praises the prohibition of adultery and of the desire for the wife of someone else in the Koran. ${ }^{44}$

Luther, who has been married since 1525 , is outraged by the attitude of Muslims on this issue, and increasingly as he grows older. In the text Martin Luther's Refutation, an afterword to Ricoldo's Verlegung des Alcoran, he states that the Islamic understanding of marriage must not only be rejected by pious Christians, but also by respectable pagans. The Islamic marriage is called an «eitel frey Huren leben», a very free living together with whores, because the husband could according to Luther's knowledge marry women at will, cast out and marry again. Such a husband is a «Huren wirt oder Hurn jeger», a host or

${ }^{39}$ Luther, M., On War Against the Turk, op. cit., p. 178; Luther, M., Vom Kriege wider die Türken, op. cit., p. 123,30-33.

${ }^{40}$ Luther refers to the permission to polygamy and divorce.

${ }^{41}$ Luther, M., On War Against the Turk, op. cit., p. 181; Luther, M., Vom Kriege wider die Türken, op. cit., p. 126,26-31.

${ }^{42}$ Hopkins, Nicholas of Cusa's De pace fidei and Cribratio Alkorani, op. cit., p. 155; Nicolaus de Cusa, Cribratio Alkorani, op. cit., \# 170,1-2 (p. 137).

${ }^{43}$ Nicolaus de Cusa, Cribratio Alkorani, op. cit., \# 156 (pp. 126-127).

${ }^{44}$ Ibid., \# 41,8-9 (p. 38). 
hunter of whores, because his wife is de facto degraded to a kind of goods. This treatment of women violates reason, the law of Moses and the Gospel. Luther calls the Islamic marriage in his typical rough way of expression a «Hunde und Sew Hochzeit», the marriage of dogs and sows. ${ }^{45}$

On the other hand, the reformer also knows many details of daily life and of the religious acts of the Muslims, which he presents as exemplary in comparison to the conditions in the Christian West. He deals with this aspect of Islam several times in relative detail, unlike Cusanus, who deals with this point only casually. So Luther writes in the foreword to Georgius de Hungaria Libellus de ritu et moribus Turcorum:

From this book, accordingly, we see that the religion of the Turks or Muhammad is far more splendid in ceremonies - and, I might almost say, in customs - than ours, even including that of the religious or all the clerics. The modesty and simplicity of their food, clothing, dwellings, and everything else, as well as the fasts, prayers, and common gatherings of the people that this book reveals are nowhere seen among us - or rather it is impossible for our people to be persuaded to them. ... Our religious are mere shadows when compared to them, and our people clearly profane when compared to theirs. Not even true Christians, not Christ himself, not the apostles or prophets ever exhibited so great a display. This is the reason why many persons so easily depart from faith in Christ to Muhammadanism and adhere to it so tenaciously. ${ }^{46}$

Regarding the military successes of the Ottomans and the supposedly more convincing outward appearance of the Islamic religion, of which not only Georgius de Hungaria knew to report, Luther was extremely worried. He increasingly felt the «Turks», i.e. Islam, as an apocalyptic threat. In this sense the Army Sermon against the Turk, written shortly after the siege of Vienna ended, interprets the almost unstoppable expansion of the Ottomans in the sense of Daniel 7 as a sign of the near end of the world.${ }^{47}$ In Wittenberg the

${ }^{45}$ Luther, M., Preface and Afterword to Brother Richard O.P. [Riccoldo da Monte di Croce], Refutation of the Koran, op. cit., p. 262; Luther, M., Verlegung des Alcoran Bruder Richardi, Prediger Ordens, op. cit., p. 393,9-18.

${ }^{46}$ Henrich, S. and Boyce, J.L., «Martin Luther - Translations of Two Prefaces on Islam: Preface to the Libellus de ritu et moribus Turcorum (1530) and Preface to Bibliander's Edition of the Qur'ān (1543)», op. cit., p. 259; Luther, M., Vorwort zu dem Libellus de ritu et moribus Turcorum, op. cit., p. 206,3-8.12-15.

${ }^{47}$ Luther, M., Heerpredigt wider den Türken, op. cit., p. 162,15-30. 
Antichrist is represented since 1529 as a being with two heads, that of the Pope and that of the Turk. ${ }^{48}$

Both the Pope and the Turk rely on outward appearance, on works, ceremonies and religious exercises, not on the faith in the gospel of Jesus Christ, which, according to Luther, alone makes us blessed. In his writings on interreligious questions Cusanus' argumentation resembles that of Luther. In chapter 16 of De pace fidei the Apostle Paul demonstrates to the wise Tartar in detail, that salvation can only be achieved by faith, not by the merit of religious works. ${ }^{49}$ Because of his early conciliarist ideas and especially his reasoning in chapter 16 of De pace fidei, Cusanus was included in the famous Catalogus testium veritatis of the Lutheran theologian Matthias Flacius, published 1556. This is an index of statements of ancient and medieval theologians, which should demonstrate, that the Protestant ideas are well rooted in the tradition of the church. Concerning Nicholas of Cusa, Matthias Flacius writes: «In libro de Pace Fidei probat nos sola fide iustificari non ex merito operum. - In his book on peace in faith he demonstrates that we will justified by faith alone, not by the merit of works. $1^{50}$

Luther's writings on the Turks encouraged those Christians challenged in their Christian faith, especially those who are in Turkish captivity, to understand that only trust and faith in Jesus Christ as the Son of God, who died for their sins, counts before God. Luther hoped, at least in times when his optimism was stronger than his despair, ${ }^{51}$ that some Turks would be converted to Christianity by the prisoners. He writes in the foreword to the edition of the Latin translation of the Koran by Theodor Bibliander, which was printed in Basel 1543 due to his intervention:

Daniel and other captives brought the king of Babylon and a multitude of others to the true knowledge of God [Dan 2:47; 3:28-29]. The victorious Goths, Vandals, and Franks were converted to God by their captives. So perhaps God

\footnotetext{
${ }^{48}$ Kaufmann, «Türckenbüchlein». Zur christlichen Wahrnehmung «türkischer Religion», op. cit., p., 47 and pp. 192-194.

${ }^{49}$ Hopkins, Nicholas of Cusa's De pace fidei and Cribratio Alkorani, op. cit., pp. 62-66; Nicolaus de Cusa, De pace fidei, eds. R. Klibansky and H. Bascour, in Nicolaus de Cusa, Opera omnia iussu et auctoritate academiae litterarum Heidelbergensis, vol. VII, Hamburg, Felix Meiner, 1959, pp. 3-63, at pp. 51-56.

${ }^{50}$ Flacius, M., Catalogus testium veritatis, Stella, Basel, Oporinus, 1556, p. 958.

${ }^{51}$ Rajashekar, J.P., «Luther and Islam. An Asian Perspective», Lutherjahrbuch, 57 (1990), pp. 174-191, at p. 187.
} 
will also now call some from among the Turks out of that darkness by means of learned captives. ${ }^{52}$

Unlike Luther, Cusanus addresses also Islamic receivers in his Cribratio. I agree with John Monfasani that Mehmed the Conqueror, about whom Nicholas said that he was a Christian in his youth, ${ }^{53}$ is the true addressee of the book. ${ }^{54}$ Incidentally, this assumption certainly fits in with the "official» intention of the work, which was to supply material for Pope Pius II for a teaching letter to Mehmed. Above all it seemed clear to Cusanus, that the more knowledgeable and sensible Muslims were aware of the obvious deficiencies of both Muhammed's character and of the Koran, and therefore merely pretended to believe in the teachings of Islam out of fear of persecution and death. ${ }^{55}$ The Cribratio is thus also directed to "the wise even among the Arabs $»^{56}$ and the "teachers of the law of the Arabs $»^{57}$ who have the capacity of discernment. It is to these readers that the Cribratio hopes to reveal the difference between the Koran and the Gospel, whose truth, Cusanus believes, they themselves are seeking.

For this reason, Nicholas also tries in the second book of Cribratio to justify the most important Christian doctrines in detail, especially the Trinity and the Christological dogmas - a task that Luther doesn't undertake in his writings on the Turks. In respect to theological questions the Reformer argues on the basis of the Bible, whose truth he presupposes, as guaranteed by God's revelation. Luther interprets the whole of reality through Scripture. In this regard, he attained a unique mastery. He rejects abstract philosophical attempts to justify Christian doctrines.

The biblical orientation of his thinking led Luther to a strict exclusivism. He saw the representatives of true Christianity virtually surrounded by

${ }^{52}$ Luther, M., Preface to Theodor Bibliander's Edition of the Koran, ed. A.S. Francisco, in Luther's Works, vol. 60, ed. C. B. Brown, Saint Louis, Concordia Publishing House, 2011, pp. 289-294, at p. 293; Luther, M., Vorrede zu Theodor Biblianders Koranausgabe, eds. O. Clemen and O. Brenner, in Luther, M., Werke. Kritische Gesamtausgabe, vol. 53, Weimar, Hermann Böhlaus Nachfolger, 1920, pp. 569-572, at p. 571,34-38.

${ }^{53}$ Nicolaus de Cusa, Cribratio Alkorani, op. cit., \# 220,5 (pp. 174-175).

${ }^{54}$ Monfasani, J., «Cusanus, the Greeks, and Islam», in T.S. Izbicki, J. Aleksander, and D.F. Duclow (eds.), Nicholas of Cusa and Times of Transition. Essays in Honor of Gerald Christianson, Leiden - Boston, Brill, 2019, pp. 96-112, at p. 107.

${ }^{55}$ Nicolaus de Cusa, Cribratio Alkorani, op. cit., \# 28,15-18 (p. 29).

${ }^{56}$ Hopkins, Nicholas of Cusa's De pace fidei and Cribratio Alkorani, op. cit., p. 149; Nicolaus de Cusa, Cribratio Alkorani, op. cit., \# 158,5-6 (p. 128).

${ }^{57}$ Hopkins, Nicholas of Cusa's De pace fidei and Cribratio Alkorani, op. cit., p. 136; Nicolaus de Cusa, Cribratio Alkorani, op. cit., \# 131,1 (p. 105). 
enemies who were active in the service of the devil. ${ }^{58}$ As mentioned in his preface to Bibliander's edition of the Koran, he included not only the Turks, but also «the defenders of the pope's idols, the Jews, a multitude of Anabaptist monstrosities, the party of Servetus, and others. ${ }^{59}$ In the whole corpus of Luther's writings on Islam I have not been able to discover any attempt to integrate or to include Islam theologically. The gospel of Jesus Christ and the message of Muhammad are always portrayed as totally opposite. Behind the doctrine of Christ God is present, behind that of the Islamic prophet the devil. Nicholas of Cusa, on the other hand, often seeks to build theological bridges between the gospel and the Koran, Christianity and Islam, however shaky some of the pillars on which these bridges are built may appear.

Walter Andreas Euler euler@uni-trier.de

${ }^{58}$ Luther, M., Preface to Theodor Bibliander's Edition of the Koran, op. cit., p. 294: «We must fight everywhere against the armies of the devil. How many different enemies have we seen in our own time?» Luther, M., Vorrede zu Theodor Biblianders Koranausgabe, op. cit., p. 572,10-11.

${ }^{59}$ Luther, M., Preface to Theodor Bibliander's Edition of the Koran, op. cit., p. 294; Luther, M., Vorrede zu Theodor Biblianders Koranausgabe, op. cit., p. 572,11-12. 
